\title{
Separating latent and acute TB
}

\author{
T Mark Doherty \\ From Immunodiagnosis of Tuberculosis: New Questions, New Tools \\ Virginia, VA, USA. 21-23 September 2008
}

In theory, immunodiagnosis should be able to discriminate between latent and acute TB, because the immunopathoogic nature of the disease means there must be significant differences in either the type and/or magnitude of immune response that develop. But so far we have not been able to pinpoint them. Our investigations of immune responses after infection suggest that in a substantial number of former TB patients, strong antigen recognition persists at least 20 years post-treatment without signs of recurrent illness. In addition, antigenspecific CD4 and CD8 memory T-cells could be detected for at least two years post-infection. In a study published in 2001, we found that healthy household contacts who responded most strongly to ESAT- 6 were more likely to progress to disease in a short time, but others who showed changes in their X-rays (meaning that they had been infected and even developed some pathology) remained otherwise healthy. An important question is whether this group is representative of natural latent infection. If that is so, similar people should be detectable in the general population and so our team looked at ESAT-6 responses in community controls. We found that although the responses to ESAT-6 were lower overall in the general population, a substantial subgroup were strongly positive. Our team's assumption is that these individuals have latent disease.

Given the results of our research, we have developed a model for analyzing latent TB infection. After initial exposure, two-thirds of the individuals exposed to TB do not apparently skin-test convert nor become ESAT-6 positive: if they have had an infection, early bacterial growth was presumably arrested fairly quickly. It is not possible to tell if they have latent TB because immunologically, they cannot be distinguished from uninfected individuals. Of the remaining individuals exposed,

Correspondence: TMD@SSI.DK

Department of Infectious Disease Immunology, Statens Serum Institute,

Copenhagen DK-2300, Denmark roughly five percent experience early bacterial growth that is not contained and, if not treated, progresses to clinical illness. In the remainder, subsequent bacterial growth is contained, symptoms abate, but latent infection is established and approximately two percent experience re-activation of the disease at a later time. The rest remain healthy, but have latent infection, which is discernible because immunologically these individuals tend to express elevated levels of interferongamma (IFN- $\gamma$ ), interleukin-12 (IL-12), IL-4 and IL-482 and strongly recognize latency antigens. These individuals are the focus of intense study because they represent natural immunity in action.

Published: 17 December 2010

doi:10.1186/1753-6561-4-S3-08

Cite this article as: Doherty: Separating latent and acute TB. BMC Proceedings 2010 4(Suppl 3):O8.

Submit your next manuscript to BioMed Central and take full advantage of:

- Convenient online submission

- Thorough peer review

- No space constraints or color figure charges

- Immediate publication on acceptance

- Inclusion in PubMed, CAS, Scopus and Google Scholar

- Research which is freely available for redistribution

Submit your manuscript at www.biomedcentral.com/submit
Biomed Central 